\title{
Collocability in Languages for Special Purposes (LSPs): Some Preliminaries
}

\author{
Francis E. Knowles, Department of Languages and European Studies, \\ Aston University, Birmingham, Great Britain
}

\begin{abstract}
This paper is concerned with the language professional discourse communities use for their internal communication. The characteristics of these languages for special purposes (LSPs) are many and varied, as well as being underresearched. The focus adopted here is to examine the phenomenon of multiword units, many of which are orthographic pluralities designating conceptual singularities. It is important to recognise at the outset that colocation is not the same as collocation. Analysis and systematisation of these textual "clusterings" is intended to separate them into two radically different types of entity: multiword segments possessing terminological status; and collocative material. The methods used to achieve the above objective are both qualitative, i.e. micro-environmental analysis, and quantitative, i.e. statistical patterning exhibiting a certain level of frequency and constancy. Collocational material quoted here also shows by its configuration that discourse communities use collocations to which the general public are not inured and with which they may not necessarily be familiar at all.
\end{abstract}

Keywords: CHUNKING, CO-OCCURRENCE, COGNITTVE ENTITY, COLLOCABILITY, CONCEPT, CORPORA, DISCOURSE COMMUNITY, DISTRIBUTION, DYAD, ENCYCLOPAEDIC COMPETENCE, LANGUAGE FOR SPECIAL PURPOSES, LEXICOGRAPHY, MENTAL LEXICON, MULTIWORD UNIT, OCCURRENCE, SOCIOLECT, STATISTICS, TERMINOLOGY, TERM, TRIAD

Opsomming: Kollokeerbaarheid in tale vir spesiale doeleindes (TSD's): 'n Aantal inleidende aspekte. Hierdie artikel handel oor die taal wat professionele gespreksgemeenskappe gebruik vir interne kommunikasie. Die kenmerke van hierdie tale vir spesiale doeleindes (TSD's) is baie en veelsoortig, en word ook onvoldoende nagevors. Die fokus wat hier gekies is, is om die verskynsel van meerwoordige eenhede te ondersoek, baie waarvan ortografiese meervoudighede is wat konseptuele enkelvoudighede benoem. Dit is belangrik om van die begin af te besef dat kolokasie nie dieselfde as kollokasie is nie. Analise en sistematisering van hierdie tekstuele "klusterings" is bedoel om hulle in twee algeheel verskillende tipes entiteite te verdeel: meerwoordige segmente wat terminologiese status besit; en kollokatiewe materiaal. Die metodes gebruik om bogenoemde doel te bereik is sowel kwalitatief, d.w.s. analise van mikro-omgewings, en kwantitatief, d.w.s. statistiese patroonvorming wat 'n sekere vlak van frekwensie en konstantheid vertoon. Kollokasionele materiaal wat hier aangehaal is, wys ook deur die konfigurasie daarvan dat gespreksgemeenskappe kollokasies gebruik waaraan die groot publiek nie gewoond is nie en waarmee hulle glad nie noodwendig bekend mag wees nie.

Lexikos 7 (AFRILEX-reeks/series 7: 1997): 70-93 
Sleutelwoorde: SEGMENTERING, MEDEAANWESIGHEID, KOGNITIEWE ENTTTEIT, KOLLOKEERBAARHEID, KONSEP, KORPUSSE, GESPREKSGEMEENSKAP, VERSPREIDING, DIADE, ENSIKLOPEDIESE TAALVERMOË, TAAL VIR SPESIALE DOELEINDES, LEKSIKOGRAFIE, MENTALE LEKSIKON, MEERWOORDIGE EENHEID, VOORKOMS, SOSIOLEK, STATISTIEKE, TERMINOLOGIE, TERM, TRIADE

D'autre part, les collocations ne sont pas des unités de lexique: tout ce qui est de l'ordre du mot - les mots composés, par exemple - devrait être écarté. Ceci est hélas plus facile à dire qu'à faire, particulièrement dans les langues de spécialité. Les associations nom + nom et nom + adjectif, par exemple, qui y sont nombreuses, sont souvent considérées, à cause de leur caractère de fixité et du fait qu'elles font référence à une notion qui occupe une place précise dans une taxinomie, comme des unités lexicales. Mais les critères de différenciation entre mot et "non-mot" (ou plutôt terme et "non-terme") ne sont pas toujours limpides. Dans un dictionnaire de collocations d'anglais général, il n'est pas trop difficile d'exclure des suites comme "generation gap" ou "battering ram", mais en langue de spécialité, les problèmes sont un peu plus complexes.

Henri Béjoint et Philippe Thoiron

\section{Preamble}

The above quotation - which, interestingly, chooses English examples to support its thesis - sets the scene admirably for what is to follow in due course on what is acknowledged to be a very significant aim, within text linguistics, discourse analysis and, of course, lexicography and terminology studies: firstly, the location within running text and the subsequent analysis - either by hand or by computer - of units of meaning which comprise more than one (ortho)graphic word; and secondly and much more importantly, the overarching phenomenon of "chunking". However, before we can sensibly discuss these matters, the major focus of this paper, we must tread a path to the promontory from which we will best be able to view the scene.

\section{Point de départ}

Chunking is a primarily mental phenomenon, the symptoms of which are to be found in linguistic formulations. Put in other terms, chunking is a psychological cause, associativity, which has linguistic effects, juxtaposition or blending. It follows that any macro-investigation of chunking as a phenomenon is best pursued by the micro-investigation of "chunks", stretches of agglutinating linguistic material which are felt to represent segments of thought rather than just fragments. Chunks are also entities about which and about the use of which 
there is some sort of social consensus. However, chunks hardly ever seem to be static in developmental terms; rather, they appear to be on a trajectory towards "explicitness" and involved in a systemic combat driven by language users and aimed at a prevaricating homeostatic trade-off between lexis and syntax. Once they have reached it, whatever that means in orthographic terms, they are no longer inchoate and they are no longer ambivalent: they have, in fact, merely become "normal", if somewhat lengthier, units of language - in common perspective, at the very least.

It is a well-known but regrettable fact that very, very few language communities possess satisfactory collocations dictionaries, the global mission of which - in addition to their strictly utilitarian function - is to demonstrate, reactively and proactively, that colocation is not collocation. The former, that is, mere juxtaposition, is either volatile or an example of a "fixed" multiword unit, whereas collocation manifests associative regularities - sometimes based on assonance, sometimes on prosodic effect, sometimes on less easily definable criteria - that can be shown to be statistically significant rather than "binary" in the sense of present versus absent. The normal unavailability of collocations dictionaries is a great pity because that is exactly what advanced learners need and, indeed, what many native speakers hanker after too. In fact, it is not stretching things too far to say that first-class collocational control is the hallmark of the true L2 expert; collocational control is, of course, normally the last linguistic subsystem to be mastered by L2 learners who proceed to an advanced level. Correct deployment of collocations is particularly important for anyone striving for authenticity of performance within a particular professional sociolect, such as the language of medicine or economics.

Lexicographic tools are urgently needed to help those who have not had the advantage, from their early years, of "statistical exposure" to lexical patterning which, although often analytically idiosyncratic, is habitual. It follows that investigation of the phenomenon of collocability relates to the hidden, subliminal patterns and rhythms of language which need to acquire a description having its basis rather in the statistics of occurrence and co-occurrence. Such lexicographical tools need to be primed - in the sense of acquiring the data they treat - by computational tools, the purpose of which is to identify, excerpt and prioritise relevant lexical material in a form suitable for subsequent lexicographical treatment. However constant this general aim may be, the actual means of fulfilling it will differ from one language to another. In all cases, of course, it is a question of locating stable and authentic multiword material - this is probably the only initial common denominator.

\section{The "intrusion" of terminology — in a double sense!}

In languages for special purposes (LSPs), a particular problem is posed by the terminological usages which proliferate in such modes of discourse. It so happens that technical terms are themselves often composed of more than one 
orthographic word. Some criterion is therefore needed to discriminate between

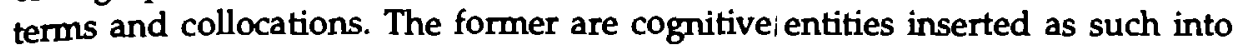
flowing text, the latter are, predominantly, inserted separately into text, yet their associativity helps that text to flow and to cohere. However, the position is given a further twist by the fact that genuine collocability also manifests itself in LSP discourse.

Let us commence by suggesting that Béjoint and Thoiron's formulation "lexical units" can be the cause of some confusion as this piece of nomenclature focuses on the messenger rather than the message, so to speak. Is it not preferable to refer to cognitive units or cognitive entities - which, naturally, require linguistic form, at least for the purposes of interpersonal communication? Quibbles apart, all of these terms attempt to capture the "truth" that it is not only words which retain their referents outside text; word-groups and phrases may also do so. This is entirely in accordance with the customs, habits and social compact established within societies for structuring individual and group experience. These lexical pointers along with whatever they point to constitute the mental lexicon of individuals and, by aggregation, the working consensus of society about how to interact linguistically with the world. Items in mental lexicons are mappings, complex rather than simple, between mental images and the names which point to them. In some ways the names are secondary and subservient: they may alter, leaving their referent unchanged, for instance. Yet they have power: names tame! The "downside" of this, via a different analogy, is that the natural dynamics of mental images are reduced to slow-motion film or even to still photographs. Yet names are also the major instrument of effability and they may acquire or discard referents as a result. Most of all, names, normally named "words", are at the very basis of social intercourse. Of course, much social intercourse takes place on a distinctly professional level, invoking/evoking - and instantiating by words - established concepts (Latin: ideas "taken together", i.e. holistically merged), phenomena or artefacts current within particular discourse communities (DCs) for the simple (!) reason that they have been professionally introduced, negotiated and subsequently validated by them. This process is necessary so that DC members can communicate with each other on the same terms, in a double sense, understanding without either external or internal mediation and not merely comprehending each other's thinking and reasoning. In this way a DC's sophistication increases, first of all encyclopaedically (at least for the pioneers) and then terminologically. The route from term to concept is immediate for DC members; for those outside the DC it is most likely. to be mediate. It can, obviously, also be a cul-de-sac. The people of a DC and their purposes always have precedence over their technolect, so to speak. ${ }^{1}$ Putting this point in the parlance of sociology, the DC even represented by its neophytes! - is the independent variable, the linguistic resources that they call on to express themselves individually and corporately are the dependent variable(s). A less obvious corollary, even to those directly involved, of this system of socio-professional "information exchange" is the 
continual growth - not necessarily linear! - in the given paradigm's cohesion. It should in fact be noted, in the margins, that this "growth" can sometimes lead to the sclerosis of orthodoxy, hopefully then followed by genuine renewal based on new relationships and a new dialectic, plus a new or at least revitalised discourse to go with them. In such extreme circumstances a DC's members may well be prisoners of their thought or "mind-set"; they are not normally prisoners of their terminology because they can realign and resemanticise it by agreement.

\section{How and where to establish a "base" for investigative purposes?}

Those who observe and analyse DCs because of an interest, even a utilitarian interest, in their technolects are almost exclusively never members of them. This, of course, puts them in the empirically best possible but still suboptimal position to carry out their work as dispassionate investigators. The position is still less than perfect because little or no regard is given to what is encyclopaedically expressible (i.e. "encyclopaedic competence"?), only to what is actually expressed by linguistic means (i.e. "linguistic performance"?). However, that is an easy statement to make. After all, there are constraints. What is more difficult is making a judicious and also successful choice of methods for the investigation. It seems that linguists are - very sensibly - increasingly resolving the problem of linguistically modelling discourse, not least LSP discourse, by primary recourse to quantitative rather than qualitative methods. Qualitative analysis of LSP discourse by "frontal attack" requires an exceedingly well-stocked arsenal of tools and techniques, many of them still evolving and maturing. The yield tends to be on a micro level, the analogy of intensive "case-study" approaches which always seem to studiously eschew any mention of "comparators" when the real questions are always the following. First and foremost, just how representative of wider practice and habits are the "findings"? Secondly, has the "gulf" between encyclopaedics and linguistics been successfully bridged? Quantitative methods offer a way round this dilemma - at a cost! These methods can summon from an arbitrarily large corpus exhaustive lists of linguistic "segments" along with their frequency of occurrence. Although the frequencies are numbers, this information is of high qualitative value because the individual items in the associated lexis can then be described in terms of their actual functional load in the running source text and also in terms of their putative "market share" in analogous "still-to-be-written" text. Such material is of prime value for pedagogical purposes, principally because it is direct and powerful evidence of authentic usage. This then is the nature and purpose of quantitative modelling in linguistics - specifically lexis in this case - and it is arguably the best route open to investigators, particularly those with strong pedagogical interests. 


\section{The crux of the matter}

We are now at a point where we can begin to draw together the two main strands of this paper. The first strand is obvious enough: how do we isolate within running text, firstly, DC cognitive units expressed by single orthographic words and how do we isolate those cognitive entities which are by definition conceptual "singularities" even though they are at the same time orthographic "pluralities"? Obviously, such matters of procedure and the variety of contingent cruces will depend on the particular natural language involved in any such investigation. ${ }^{2}$ In some languages, of which German may be taken as a suitable representative, the linguistic designation/configuration of many concepts, both within everyday life and within specialist DCs, often occurs via the compounding of separate lexical items into one orthographic unit. The linguistic process involved is one of holisticisation - who can say whether this is a true reflection and model of the Gestalt formed by the fusion of the latent (!) mental constructs? Just as the concept is "taken together" and becomes molecular, so the component [Latin: "putting together"] names are similarly batched and merged:

Farbfernsehempfänger, [Farb[(fern/(seh)[empfänger]]]:

colour television receiver, [colour_[(tele)/vision]_[receiver]]];

Preisfestsetzungsrichtlinien, [Preis[fest[setzungs[(richt//linien]]]]]: price-fixing guidelines, [price-fixing_[guidelines]].

English achieves the same objective of terminologically nominating a concept by juxtaposition and/or hyphenation. Phrasal formulation is also often an option in English: guidelines for price-fixing / guidelines for fixing prices. ${ }^{3}$ It should be apparent, even on this slender basis, that delineating technical terms in running text is not an easy business as far as English is concerned. It is, of course, not unimportant which of the three available methods a language uses, and in what "mix", for structuring syntactic meaning: element order, function words, or inflection. The characteristics of English, with its "residual" inflection and consequent reliance on "neighbourhood" are particularly impervious to analysis by traditional methods. The chunking phenomena' of interest yield only to subtle environmental analysis, often supported by statistical profiles. An instance of this is the English "phrase term"

stability augmentor pitch axis actuator housing support

which brackets as

[[[I[stability augmentor] [pitch axis]] actuator] housing] support]."

See also Appendix I for a brief excerpt of text on navigation ${ }^{6}$ with terminological usages "coded up" — in an intuitively simple manner — as single ortho- 
graphic words. The paragraph shown represents only about one tenth of the entire text but the artificial graphic system used cuts the token count by 70 items, while - because of the batching effect - reducing the number of types by only a mere half dozen!

\section{A fundamental distinction and its implications}

It is vitally important to understand that the formation/usage of such multiword units in English - and in many other languages - has nothing whatsoever to do with collocability, the chronologically second but thematically and substantively first strand in our discussion. It is a fact of life that, alongside everyday collocations of greater or lesser currency, professional collocations also exist. It is to this feature of language that we now turn our attention, encouraged and helped by the following dichotomising principle: If multiword units are terms they are not collocations; if they are collocations they cannot by definition be terms.

Operationally and computationally, this principle reduces to the need to distinguish in English between those spaces between orthographic words which separate and those which glue and bond. Fortunately, this problem normally solves itself in the course of computer-driven analyses by dint of the statistical force of grouping.

\section{Collocation: a macro phenomenon with micro differentials}

Collocation is a linguistic phenomenon which manifests itself via the habitual but often seemingly idiosyncratic or inexplicable' association by co-occurrence in a microcontext, in parole, of one word with another. The strength of such associations may vary, both within a community and over time. There is some basis for stating that collocation is a phenomenon which can partly be measured in terms of its surface systematicity. Collocation is a linguistic subsystem which individual L1 users acquire, as noted above, not by study but by sheer exposure to the phenomenon from their early years on. Each new stimulus adds incrementally to the speaker's ability to control his/her own linguistic behaviour and to make certain judgements about other people's linguistic behaviour. In many ways, collocational control - which also embraces the ability not to produce incorrect collocations! - is not merely a hallmark of linguistic maturity, it is also a kind of shibboleth. That is why it is so important - it is also why collocational control is difficult to master, seriously so if the person attempting to establish control is not a native speaker of the language concerned. Such a persion has to adopt or devise a chronologically optimised regimen for acquiring collocational control: the problem is that emulation of native speakers is too slow and simulation is too risky. The simulation has to be con- 
nectionist anyway, developing its own neural network, to use two terms in a literal rather than a metaphorical sense.

Given that collocations occur freely and naturally in all those sociolects which are "everyone's property", it would be somewhat strange if they did not also occur in special languages, the LSPs associated with and "owned" and regulated by DCs which group professional persons by gradations of various types. It is a very pertinent - and underresearched - question as to whether exposure to the collocational habits of technolect speakers instils collocational orthodoxy of linguistic behaviour in the same way as in general circumstances. One hypothesis must be that there are differences between the two situations alluded to. People joining obvious professional groupings do so at a time in their lives when their adult native language habits are more or less established. Nonnative speakers have a more obvious problem. Either way, there is a learning and adaptation process which has to be much more purposive and "supraliminal"; this, in its turn, requires deliberate reflection, learning and greater awareness about linguistic, sociolinguistic and metalinguistic matters. The urge to adopt "group-speak" is more keenly felt even if "group-thought" lags behind somewhat! Yet there is an ongoing tension between the demands of the logical and ontological framework of the professional DC and the requirements of illocutionarily successful linguistic formulations and terminological codifications. The "genre" problem within a DC's discourse is an added subtlety, not least in terms of the collocational practice of DC members vis-à-vis other DC members or "layfolk", to name only one such communication axis.

\section{A LSP-based investigation of collocability}

The (ongoing) research on which the above remarks are based is an investigation of LSP discourse in the areas of finance/banking and - partly - of medicine. The texts used in the investigation come from two types of source. Firstly, the holdings of the Aston Scientific and Technical English Corpus (ASTEC) provided the medical text. Secondly, and quantitatively more importantly, the finance and banking material was read from a commercially available CD-ROM which contains the entire text of the 1993 editions of the Financial Times, classified into subcorpora designated by theme and genre.'

Once a prima facie satisfactory corpus of text has been identified, it can then be processed. For very large corpora (i.e. 2 million tokens) the machine processing is carried out in a UNDX environment, via a suite of programs expressly designed for the purposes described in some detail here. The method of initially selecting and then identifying multiword textual segments is simple enough. The objective is to find, inspect and count batches, no more than arbitrary fragments really, consisting of nine orthographic words. Once found, these fragments can be sorted and arrayed by their "middle", i.e. fifth, word. The scanning window then moves one word to the right, so to speak, and iterates the same basic process. Some further sophistication is available - at addi- 
tional computational expense - by the following method which has been shown to be operationally viable with groups of two words (dyads) and three words (triads). The algorithm works as follows: in the case of dyads, the words comprising them must be within a sentence boundary, with no intervening punctuation marks. Neither member of the dyad may be a function word. For triads the strategy is similar, with the "concession" that the middle word in a triad may be the function word of. The yield, unlemmatised, from the algorithm is sorted by frequency and then inspected with a view to identifying segments rather than fragments. Many of the segments are proper names, either institutional or personal, of encyclopaedic significance to the DC concerned. Those that are not are either terms representing cognitive units or they are potential collocations. A list of 553 triads - representing occurrence frequencies descending from 308 to 3 inclusive - was derived, by the above "unintelligent" methods, from a sample of the World Stock Markets corpus. Of the items in this list $62 \%$ represented cognitive units (interest rate cut), proper names (UBS Phillips Drew), jargonistic turns of phrase (dealers took profits), or collocational expressions (volume remained flat). Similarly, a list of 1268 dyads - representing occurrence frequencies descending from 431 to 5 inclusive - was then derived from the World Stock Markets corpus. Of the items in this second list $44 \%$ represented the same set of lexical categories: cognitive units (corporate earnings), proper names (Bill Clinton), jargonistic turns of phrase (depressed sentiment), or collocational expressions (Paris fell). An analogous analysis of a medical corpus drawn from the British Medical Journal yielded 121 terms from a list of 883 triads (see Appendix II).

Computational experience has shown, at this stage, that the main operational requirement is copious output which can then be refined by classification even if the discard rate is high. A surfeit of information is better than a dearth thereof! The steps needed to achieve copious output are easy enough to understand and appreciate. A large corpus will yield a rather long list of types, to which is appended the number of tokens for the relevant type, that is, its occurrence frequency. No attempt is made at all to group the types together into their "lemma set" and hence attempt to look at the behaviour of the canonical form. This can be done separately for English text, but even for inflected languages (such as Polish) it is more profitable in fact to look at the types independently of their lemma "allegiance". The point is that the various forms of the lemma all lead different lifestyles in text, not just in terms of frequency but also in terms of the lexical company they keep. The grouping action of lemmatisation actually obscures important information about type frequency and functional load within text and - above all - about type behaviour in terms of semantic differentiation. Be that as it may, it is probably the type frequency list (plus token counts) which is the main priming material for further investigation. Clearly, the analyst has choices to make, invidious choices, possibly. Attention tends to gravitate either towards types with a fairly high frequency or towards items of almost curiosity value. Having once selected an item for 
further scrutiny, the analyst goes back to the corpus and retrieves all the lines containing the item in question. This is the necessary preliminary to the study of the said item's distributional characteristics - that is, seeing how its meaning is "defined" by the constancy of its neighbours, its morphological variants and, if such applies, its - often Janus-like - polysemy (see Appendices III and IV). This is, in fact, the only logistically feasible way of studying words as "chameleons". It can be noted in passing that any search profile can be entered as a string rather than as a fully-fledged word if interest is actually focused on a lemma or hyperlemma (as in the set: STRUCture, reSTRUCture, STRUCtural, STRUCturalism, deSTRUCtion, conSTRUCtive etc.). The result of the actual search is a set of one-line concordance citations which may supply information that is adequate for the analyst's purposes. If this is not the case, the entire sentence from which the keyword has been somewhat artificially extracted can be retrieved for inspection. As a further specific aid to collocational studies, a so-called synoptic chart (see Appendix V) can be produced of the node's left and right neighbours to a depth of four items. The individual items arrayed are "decorated" with their own occurrence frequencies. This is the basic method of attack for the purposes of collocational analysis but it is worth mentioning in this precise context that an overview of the valency pattern of the node words selected often also comes across very forcefully. Valency patterning is, of course, held by some to be an integral pattern of collocation studies. The techniques enumerated here have also worked, incidentally, to good effect on material in languages other than English.

It is clear from the initial stages of the above ongoing programme of research into LSP collocability that, as regards text generation, a marked degree of formulaic writing exists in the World Stock Markets financial press. This is true with respect to sentence structure and to the choice of words used for the purposes of qualification. This is either a tendency to avoid any disorientation in readers' minds that might be caused by novelty of usage or - just possibly - the result of summoning up, by reason of time pressures, certain prefabricated utterance structures of an algebraic kind and leaving the few variables mostly unchanged (see Cowie 1991 and 1992).

The techniques described immediately above achieve their greatest effect in the way they present for inspection the left-hand and right-hand neighbour(s) of the nodes chosen. Scrutiny of these environments leads naturally and fairly rapidly to the identification of any collocations present. Let the professional collocations used to describe the quality of stock market trading in Appendix VI speak for themselves and invite reflection, but let not the merits of the material in Appendices II, III and IV be overshadowed in the process!

\section{Implications and Renvoi}

The implications of what precedes are numerous but can nonetheless be classified as either practical or theoretical. Let us deal with the practical implications 
first. Computationally, the impediments impinging on both principle and practice are minimal. Largely, the name of the game continues to be the game of the name! In terms of particular investigations a great role is played by pedagogical impetus: in fact, the agenda can safely be driven by this as no gulf is likely to open up between those who seek and find material ${ }^{10}$ and those who place it in the lexicographer's/terminographer's crucible.

On the level of theoretical considerations, there is much more to speculate about. Let us ask some questions which are not merely rhetorical. What is the precise nature of the mismatch between orthographies and the cognitive units they must find designations for? What is chunking - with respect to term formation and collocability - and how can synchronically- and diachronicallyfocused studies be pursued with both descriptive and analytical purposes? How does the primeval soup of language congeal in different ways and in what contrasting and competing ways within particular languages? What is the logical, semasiological, ontological and analogical nature of, say, the sets (or classes?) of adjectives collocating with certain nouns or groups of nouns? Is this all sui generis or is it describable in generic terms?

\section{Acknowledgement}

I am very grateful indeed to Anthony P. Cowie for his expert and penetrating critique of this article and also for several suggestions about how it might be improved, all of which I have adopted with alacrity.

\section{Notes}

1. For further discussion of the linguistic and saciological basis of DCs, see Knowles 1997.

2. Let us, for the purposes of this discussion, set aside the cross-cultural differentials and the occasional mismatches between the encyclopaedic networks of "national" DCs. Such mismatches cause communication problems by cropping up in LSP discourse potentially addressed to all members of a supposedly international and "shared" specialist/intellectual culture.

3. It may be that German's/Germans' tendency to generate complex/compound neologisms in the form of large numbers of one-word lexicalisations (their words are Komposita or Zusammensetzungen!) is explained not just by the linguistic resources available but also by holisticising perceptions.

4. Languages such as Arabic possess a mechanism known as iDaafa (annexion) in which two (occasionally more) words, while remaining orthographically separate, unite to form a separate cognitive unit. An instance of this is Arabic ra's maal, literally head of money, i.e. capital. These units are fully lexicalised and are atomic in the sense that no other linguistic material may be interposed between the two orthographic words involved. Hebrew, Farsi and Turkish also have very similar structures. Note that these compounds are exactly that, they are not collocations, although collocation might well have been their origin.

5. See Varantola 1984: 42.

6. From the article "Navigation" in Amerongen 1977.

7. Why do English speakers always enter a caveat? Enter, here, is a truly transitive verb, a usage very different from "entering" a building. 
8. I express a great debt of gratitude to Patricia Thomas and to my close colleague Dr. Peter Roe for insights gained from the many continuing conversations we regularly have on the matters discussed here. A particular vote of thanks is also due to Peter for the specification and implementation of the ATA (Aston Text Analyser) software package which is now under commercial development.

9. We express our sincere gratitude here to the FT for permission to make extensive use of the CD-ROM materials.

10. Terms or collocations - on this occasion we draw no contrast!

\section{References and Bibliography}

Aarts, J. and T. van Heuvel. 1985. Computational Tools for the Syntactic Analysis of Corpora. Linguistics 23: 303-335.

Amerongen, C. 1977. How Things Work 1. Translation by L. Zgusta of Wie funktioniert das? (Mannheim: Bibliographisches Institut, 1963). St.Albans: Granada.

Bejoint, H. and P. Thoiron. 1992. Macrostructure et microstructure dans un dictionnaire de collocations en langue de spécialité. Terminologie el Traduction 2/3: 513-522.

Burger, H. et al. 1982. Handbuch der Phraseologie. Berlin: De Gruyter.

Church, K. and P. Hanks. 1990. Word Association Norms, Mutual Information and Lexicography. Computational Linguistics 16(1): 22-29.

Cowie, A.P. 1991. Multiword Units in Newspaper Language. Granger, S. (Ed.). 1991. Perspectives on the English Lexicon. Louvain-la-Neuve: Cahiers de l'Institut de Linguistique de Louvain.

Cowie, A.P. 1992. Multi-word Lexical Units and Communicative Language Teaching. Amaud, P. and H. Bejoint. 1992. Vocabulary and Applied Linguistics: 1-12. London: Macmillan.

Fillmore, C. and B. Atkins. 1994. Starting where the Dictionaries Stop: The Challenge of Corpus Lexicography. Atkins, B.T.S. and A. Zampolli (Eds.). 1994. Computational Approaches to the Lexicon: 349-393. Oxford: Oxford University Press.

Fontenelle, T. 1992. Collocation Acquisition from a Corpus or from a Dictionary: A Comparison. Tommola, H. et al. (Eds.). 1992. EURALEX '92 Proceedings. Papers submitted to the 5th EURALEX International Congress, Tampere, Finland: 221-228. Tampere: University of Tampere.

Knowles, F. 1997. Lexical Carthography. Somers, H. 1997. Terminology, LSP and Translation: 125140. Amsterdam: Benjamins.

Morgenroth, K. 1993. Le terme technique. Tübingen: Niemeyer.

Pavel, S. 1993. La phraséologie en langue de spécialité. Méthodologie de consignation dans des vocabulaires terminologiques. Réseau International de Néologie et de Terminologie (RNT) 10: 67-82.

Pilz, K 1974. Phraseologie. Stuttgart: Metzler.

Rousseau, L. 1993. Terminologie et phraséologie, deux composantes indissociables des langues de spécialité. Réseau International de Néologie et de Terminologie (RNT) 10: 9-13.

Sager, J.C. 1990. A Practical Course in Terminology Processing. Amsterdam / Philadelphia: John Benjamins.

Sinclair, J. 1991. Corpus, Concordance, Collocation. Oxford: Oxford University Press.

Skehan, P. 1996. Second Language Acquisition Research and Task-based Instruction. Willis, J. and D. 1996. Challenge and Change in Language Teaching: 17-30. Oxford: Heinemann.

Varantola, K. 1984. On Noun Phrase Structures in Engineering English. Annales Universitatis Turkuensis, Series B, 168. Turku: University of Turku.

Zgusta, L. 1967. Multi-word Lexical Units. Word 23: 578-587. 


\section{Appendix I}

As the water_depths are marked on nautical_charts, a further navigational_aid is provided by soundings, i.e., systematic measurements of the depth_of_[the]_water in which the ship is sailing. The traditional device for the purpose is the lead-line. Patent sounding_machines are based on the fact that the pressure_of_[the]_water on an immersed body increases with the depth to which it is immersed. A more modern device is the echo_sounder. In the bottom of the vessel's hull a transmitting_oscillator and a receiving_oscillator are so mounted that the latter picks_up the echo reflected_back from the sea_bed A rotating_contact causes a condenser to discharge through the electromagnetic transmitting_oscillator, so that a sound_impulse is transmitted. The timemeasuring_equipment comprises a neon_lamp rotating in front of a timing_scale. When the lamp passes the zero_position, the sound_impulse is transmitted. The time it takes for this impulse to reach the sea_bed and return to the receiving_oscillator (which is essentially a microphone for picking_up the sound) is marked, or read, on the scale by a flash emitted by the neon_lamp, which has meanwhile rotated past the zero_position. The current from the receiving_oscillator has to be amplified in order to cause the lamp to light_up. Echo_sounders usually operate with ultrasonic frequencies $(20,000 \mathrm{cycles} / \mathrm{sec}$.), but sounders operating with an audible sound_frequency ( 3600 cycles/sec.) are used for deep-sea soundings. The principle of the transmitting_oscillator is really quite simple. The coil is energised by an alternating_current with a frequency of 3600 cycles/sec., so that the laminated armature, attached to the diaphragm, is alternately attracted and released. The diaphragm emits sound_waves of this same frequency. Other types of transmitter make use of the principle of magneto-striction or the piezo-electric_effect. 


\section{Appendix II}

958 confidence intervals absence of menstruation active group odds additive adverse effects adverse neurodevelopmental outcome adverse neurodevelopmental sequelae alternative metabolic substrates analysis of subgroups antepartum breech presentation antepartum cardiac disease artificial insemination clinic asymptomatic-neonatal hypoglycaemia Bayley mental scale

blood glucose concentration

blood glucose concentrations breech multiple pregnancy cardiac antepartum haemorrhage cardiac breech presentation central dellvery suite centre d failed

computerised collection system continuous dependent variables controlled cord traction cycles of treatment days of ventilation degree of hypoglycaemia degrees of hypoglycaemia Department of Health detailed neurological examination development of nypoglycaemia diagnosis of postpartum diastolic blood pressure dichotomous dependent variables distribution of conceptions distributions of insemination early breast feeding early childbearing years early feeding practices elective intravenous nutrition empirical cumulated distribution enzyme immunosorbent assay fatness mass index

fetal growth retardation frequency of inseminations frequency of intercourse frequent moderate hypoglycaemia full term infants

full term neonates gamete intrafallopian transfer glucose oxtdase method Health Ethics Committee higher susceptibility rates nighly significant increase hypoglycaemia glucose concentration hypoglycaemia plasma glucose nypoglycaemia recurrent apnoea hypoglycaemic neurological impairment iatrogenically controlled ovulation immedlate postpartum period incidence of hypoglycaemia incidence of postpartum incidence of vomiting insemination donor clinic late maternal refusal local awareness campaigns major congenital abnormalities maternal blood loss maximum regression coefficient maximum sperm counts mean birth weight mean cell volume mean gestational age mean monthly temperatures measure of non-compliance mental development scores mental developmental scores method of testing methods of testing middle postpartum haemorrhage minimal enteral feeding minimum safe plasma mothers' educational level motor development scores multiple intrauterine death neonatal cell volume neonatal packed cell non-parametric sample test number of conceptions occurrence of hypoglycaemia onset of hypoglycaemia packed cell volume persistence of hypoglycaemia plasma glucose concentrations postpartum cell volume proportion of infants proportion of susceptible quality of semen raised blood pressure randomised controlled trial

rate of conception

rate of ovulation

rate of postpartum

rate of susceptibility

rate of uptake

rates of conception

rates of uptake reduced developmental scores regional health authorlties Registrar General's Classification release of gonadotrophin

risk of hypertension

risk of postpartum senior house officers severe neonatal hypoglycaemia severe neurological damage somatosensory evoked potentials special care nursery treatment of infertility waste of eggs World Health organisation

[121 of 883 triads retained] 


\section{Appendix III}

16 APR 92 / Observer: A mucky hich has a staff of 8 , trenanect encounters: there 1a unfiniahed $r$. And all at the bottom of tho hey will lead to more lucrative hion houses are reporting briak oup's managed puba and property of its US-based henltheare having run tho

ot of time casting doubt on the the DTI's efforts to make $t$ not according to Bill Emmott, eeking to transfer its non-11fe tax' on

for domeatic mortgage Indamity However.

were a Iamily sex, women, blg Dalgety regarded agri Giovanni Di stefano, a former aling rotail

The average rate of proportion of

the HE traditional split in Genoa's The

sectors of the nd significant support within a jobs, some members of the local the city's The Canada's and the bulk of Canada's shifted from politicians to the

DALGETY, the foods and agrisome

1 contracting marketplace where which indicated that improvement in

on

The closely-watched Index of

profitability in spite of max th the Hoar brothers over their FT 13 JUN 92 / Japanege the Bank of Japan reported that the Bank of Japan reported that decline in

to the 333 companies surveyed, FT 13 JUN 92 / Japanese Lybrand - records an upturn in $r$ Dean, aged 53 , is a freolance aation of profits, there was no

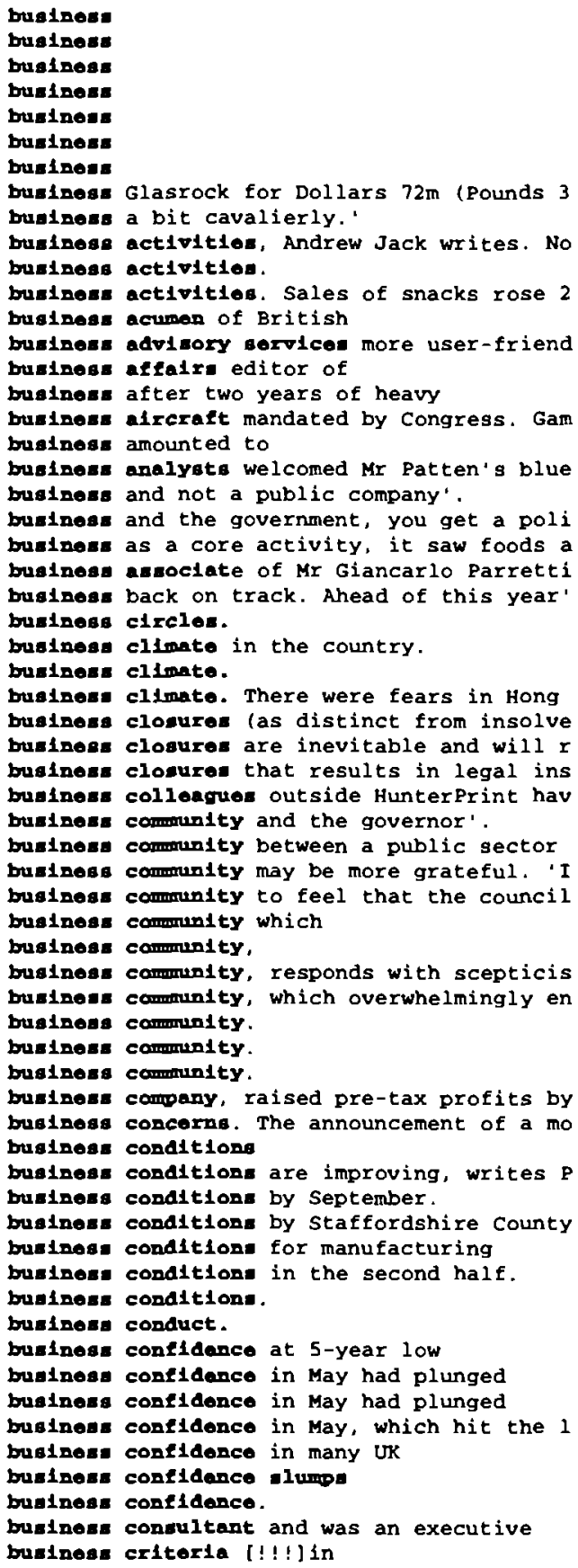


similar He argues that Japanese many of their

street banks' charges to mallre optic circuits to link local ochester says some Lloyds mallcombination of a reviving nat United was trying to link a and

Mr Tim Baker, The

1 months before he died and his $\mathrm{mi}$, inherited almost the entire largest jet, expensive cars and various how to respond to the alfelcult warned that the Japanese political and mainly targets the that becauge there have been so many m committing one of the biggest attract night stay in a Marne la Vallee trippers or staying at nearby its

US and Wellworth food retaling d standards and with its own 39 / Turkish fears grow on foreign I might place some of its amall te and the postponement of many be said that many, if not most

he company along with other agrl

9 , has resigned to follow other production and elat February d yesterday showed the ratio of terday showed that the ratio of business rates impose on ' Our core Brothers of Belfast, and the US to power the new Gulfstream GV

flight of the new It is true the and billed as the fastest-ever ion last year. However, the 186 - find an education pundit or a However,

Mr hata was responding to A timely combination of new prothough the company that once had a booming een told that his parliamantary 'The governmant' : egraAy

will help governmant' tactics by banks in the amall ple is commonplace in the amall fares may benefit the asset. They are ateeped in the it will be the in monitoring the buslneve culture and language. In 1980-88, buslnese culture in which discipline bualnese culture will change to allow other bualnese cuatomera - a question highlighted buelneas customers are builnese customera directly to

buelnees cuatomere would save at least 20 buetnere cycle and fiscal stimuli from a ne buelnese deal with

bualneas dabte do not together make a stabl buelnees development manager with Norwich U bualneas developmant unit of Manchester Bus bustnees entro

busineas explre except for seibu

businese emires in Italy (Agnelli's Juvent brelneve enterprises. Only Pounds buelnese environmant has

bueinese environment would become increasin buelnese ethice being called into question. bustnese execut1ve and conference market.

businese fallures early this year were run burlnese fallure in the sector) to

bualneas eraud of the

bualneas from Taiwan.

buelneas hotel.

buglnese hotele at cut-price weekend rates.

buelnee houre to encourage more trading. B

bualnese in Northern Ireland.

buelnera Indicatora. 'Unless an

burines. inelux

busineas InItlatives with the shops if

bualnese intelativer.

burinear ingolvencle:

businesa Insolvencies throughout the period buginene Intereste in the under-developed $r$ buglnese Interesta to concentrate on core bualneas Interenta, writes Terry Hall in bualnees inventorles - were in line with buelneas inventories to

buginega inventoriea to

business Investmant in buildings and the co

burlnese is the development, production and bugineas Jet

burineas jot aircraft. The order

bualneas Jet at Farnborough to meet the nee buglneas Jet is due in late 1995 .

bueinea. Jet market held up rather better $t$ buelneas jet.

buelneas Jete sold, although 10.7 per

bufines: leader who agrees

bualnese leadere and conservative oppositio bualnese lender" disquiet as the Nikkei in buelnes: legialation and important

bualness levela remained well below normal buelnese lobby, such as Mr Jacques Calvet, buelnes: making costly, top-quality sports buelnese managera

buelnese managere will be desperate to bull bualnese managers, unlike their national re bualneas managera. However, it seems the st bualnese market, and constant rumbles of businese market, though. Other buelneas market.

bustnese of

burinean of David Mollor, the new minister; bueinede of governmant. He promised more op 
months, net profit from normal for Unilever's agri profits from normal

industrial wasteland into a permission for a large permission for a large eisure district, most of the 22 promoting promoting

t company specialising in large in large at least seven

Mr Jaffe is an old friend and one customer orders with their own Britain's battered mall $s$ that 'there are many Japanese they are ative fundraising efforts among on

ompany News: R. H. Macy unvolls urgently reviewing its

at the new

look at the project when the ould look at the project if the nformation we will finalise our part of the airline's E1vo-yoar unvolled a Elvo-yoar reached Pounds $1.65 \mathrm{bn}$. The iery have yet to couplote tholr As part of JAL's imoto, general manager of Asian

'put together 15 of the last 16 standing commission on laws and ftware company who says: 'Their

To counter tho proved itself a useful their lending margins. So basic ough trading conditions cut agr domatic and vey says that uncertainty about acco and insurance group's good uniform The

Councils pay tholr ear 95 per cent of the assossed government grant and the government grant and the

pointing out that

whatsoever for stripped out to avoid capital-intenel vid when customer rotall decisions and would not affect stacle in bullding conetructivo $t$ the well-publicised series of businese operatione

businese operations recently put up for sal businese operations would be about half the businese opportunity.

businese park for smaller industrial and se buelnees park in partnership with the churc businese park, industrial areas and housing bustnees park.

bustnese parke are on the periphery.

businese parke in the north-east, are not $p$ businese parke in the north-east, are not $p$ bustnese parke,

bustnese parke, has asked National Westmins buelness parke, there are hundreds of acres buslnese partner of $\mathrm{Hs}$ Lansing's.

businese partner reporting on the ripeness businese partners.

businese people need is panic action to ref bustnese people who

bustnese people, judges or politicians.

businese people, led by its deputy

bustnese performance confirmed the broad we businese pessimism, and the political hiatu bustnese plan

bustnese plen and may decide to sell core o businese plan for the company, says that th bustnese plan once it was complete and had buelnese plan to lenders later this month a bustness plan was complete.

businese plan were

buelnese plan which

buelnese plan which it updates

bustnese plan which, it claims, will 'retur business plan written in spring last year $h$ businese plan, in spite of

buelnese plen, the airline plans to open at businese planning at Itochu,

buelnese planning has been based on very co bustness plang

businese practices

buelness practicen are reminiscent of

buelnese probleme, the company has plans to buelnese product with a finite constituency businese proflte for the year

buelneas profita to Pounds $11.9 \mathrm{~m}$ from

businene property costs such as rent levels bualnese prospects is still holding

businese prospecte prompted profit

buelnese rate in 1990 , brought in an estima buelnese rate is set by the government. but buelnese rate revenue into the national non bueinese rate was collected

buelnese rate. However, the Department of $t$ businese rate. This year, though, The Depar bustnose rates - and council tax when that buelnese rates - and council tax when that buelnese rates could lead to unexpected inc buetnens rates had been cut by pounds 1.25 b bualness rates impoe on business invest bustnese rates non-payment. .

buelnese rates were "the tip of a nasty ice businese rather than one which generates a buelnese reached Pounds $1.154 \mathrm{bn}$. buelneas relationohipe between the two businese relationehipe". buelnese ecandele in Ireland pointed 
rsity of strathelyde's graduate provided ach, both geographically and in As for the lucrat ive the apparent opposition of the

The tankan, reflecting poor Banking, insurance and BET, the

PRE-TAX profitg at BET, the

FT 16 APR 92 , Boost in and

The latest review of dy progress on all parts of our over

departmant of $y$ important role in galvanielng cant upper floors can now grant lord and Tenant Act which gives anything in

things are profitable in general fall in a declina in

ds to attract more tourists and In 1989 Dan-Air's chartor The new e Us has formed a new worldwide

The new GPT has eat up a many

ietratogic

In the life insurance sector, There was also a slight rise in Increase in d today. However, it warns that ncial services companies expect

A sizeable amount of the day's core of the ales at the Darchem engineering side of the boaltb ating profit for that enctor of traditional way of dolng women hoping to set up in mphasising that any recovery in ambargo on lient has tried to carry on tho time they are charing us to do in its extraordinary losses was rritory might remains 'the most wirtschaft in cologne, a The proportion of and exclude Spencer's nlcho foode clear alons of an upturn in from its malnetrenm

full, and doing a thriving involved in lending to a mall group was looking to buy a core bustnese school.

businese chool acrosg the world with a cl business sector terms, to take

buelness sector, 'which has earned a massiv bustnee sector.

business ector.

busidese sentimant, out next week, before $m$ businese sentimont, prompted a fall in the bulinece services 13.48

buelnese cervices conglomerate, is likely businese services group, could have been al buelnese servicen have both recovered lost businose upanding forecast

buldose stratogy for years to come - is no buelnese stratery goes further than a simil buelnese atrategy.

buelnese stratery.

buelnese studies.

buelness eupport in recent weeks.

businese tenancles to housing

buelness tenante the right to

buelnese terms," he reckons. Meanwhile he i buselnese terme."

buselnee travel and tourism.

businese travel caused by the Gulf war and buldees travellere more choice.

businese travellera.

business turned over about twice as much as buelnese unit consists of three product ope business unit focused

business unit to gell its new Canadait Regi buelnese unit' misgion is to build, on top buelnese unlt, GPT Cablecom, to tackle the buelnees undt: beneath those groupg in its busines units (SBUs) in Vevey for each Ne buelnees unite.

buslnee volume in the insurance indugtry businese volume are still depressed and businese volumes during the quarter, the businese volumes in the next three months. businese volumes remain well below businese rolumes to business was holding up, helped Great Unive busines: was reported to have come from the bue1nese was smokers accessories. Today, $p$ buelnese ware bard hit. They fell from businese w11 attract compet1tion, but is $c$ budness will be lower. Last year 54 per burinese will be threatened by the new law. buelnese will have access to female busi buelnese will start from

buelnese with Hanol, the sengitive issue ma businese with a view to

buelnese with us, not

businese ritedown and closure

buspen-erlendly location in

buslnese-orlentated research institute, say buelneas-related bankruptales to total indi bue1noese-rolated individual berruptcies ac buelnee-related Individual benkruptcles, w buelnees.

businese.

buelnese.

businese.

businese.

buelnees. 
or from the Freemans mall order nearby to handle the rolum of $\min 11$

pending is put the way of bleck that only gangsters are in the they are et111 in ers were informed, was open for kely to remain in charge of the $y$ no comprehension of running a this week, had we been in unning a town is like runnting a in turning round the or banking ince 'they are part of our core everyone gete buxnt in the $111 \mathrm{~m}$ are always soliciting now go out of omers) is somethlng rare in our in this country to austain the

[278 citations retained out of 984 ] bucinese.

buelnese.

buelnese. 'You don't

buelnees. But the success of $\mathrm{Mr}$

bualnea. But there are too few of them lef

buslneee. Foreign investors were

buslnese. He will

buelneee. So

buelnese. To illuminate my purpose and dero

buelnese. Unless you continue to

buelneee. When he foined Midland in 1987

bus 1nees."

buelnese. '

businese."

bualnese. '

businese."

buelnese."

\section{Appendix IV}

ws: Harland simon may sell core istoric buildings with 100 tech cretionary portfollo management

for $\operatorname{tin} 11$ per1pheral closure of 10se-making on which has sent so many ma11 Small scale tamlly-run omer-occupler

rticultural and consumer health information technology As one of the two core

interested in selling non-core elling some of the private alde health inaurance portfollo of oup noticed a plak-up in tta Us lised approach to running thelr)

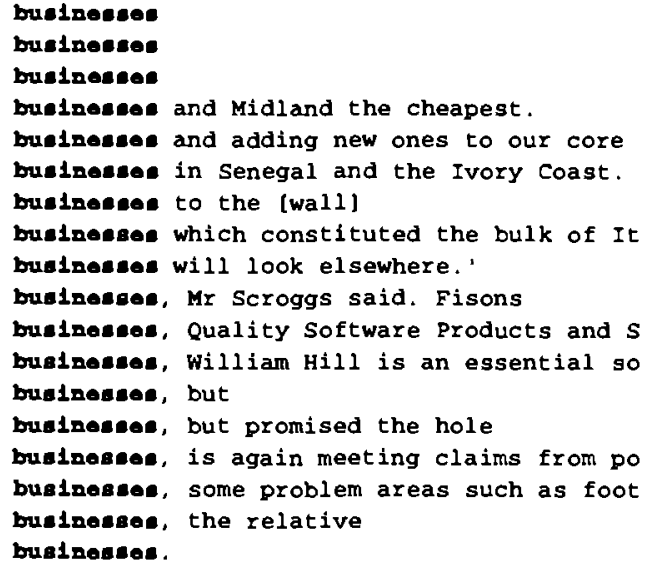




\section{Appendix V}

\section{SYNOPTIC CHART FOR 'BUSINESS'}

\begin{tabular}{|c|c|c|c|c|c|c|c|c|c|c|c|c|}
\hline 51 & the & 71 & the & 91 & the & business & 59 & and & 53 & the & 45 & the \\
\hline 42 & of & 62 & of & 45 & of & business & 36 & in & 27 & in & 21 & to \\
\hline 32 & to & 30 & a & 27 & $\mathbf{a}$ & business & 29 & is & 23 & to & 17 & $\mathbf{a}$ \\
\hline 23 & in & 29 & in & 26 & in & business & 25 & of & 21 & and & 16 & of \\
\hline 14 & its & 20 & to & 19 & its & business & 22 & which & 18 & $\mathbf{a}$ & 14 & and \\
\hline 13 & a & 19 & and & 17 & and & business & 22 & was & 13 & not & 10 & its \\
\hline 11 & is & 17 & its & 15 & new & business & 18 & has & 13 & has & 10 & be \\
\hline 10 & and & 10 & for & 13 & that & business & 16 & to & 12 & for & 8 & it \\
\hline 8 & for & 8 & on & 13 & The & business & 14 & with & 10 & of & 8 & in \\
\hline 7 & that & 7 & or & 12 & small & business & 13 & plan & 10 & is & 8 & as \\
\hline 6 & with & 6 & is & 11 & for & business & 11 & for & 9 & which & 7 & an \\
\hline 6 & as & 6 & his & 10 & core & business & 11 & community & 9 & be & 7 & by \\
\hline 6 & The & 6 & UK & 7 & their & business & 10 & will & 8 & been & 6 & with \\
\hline 5 & an & 5 & up & 7 & our & business & 8 & would & 8 & are & 6 & is \\
\hline 5 & core & 4 & out & 7 & an & business & 8 & rates & 7 & said & 6 & been \\
\hline 5 & at & 4 & more & 6 & to & business & 8 & conditions & 6 & would & 5 & not \\
\hline 5 & are & 4 & general & 6 & retail & business & 8 & as & 6 & at & 5 & has \\
\hline 4 & who & 4 & at & 6 & hotel & business & 7 & confidence & 5 & he & 5 & Pounds \\
\hline 4 & up & 4 & an & 6 & banking & business & 7 & $1 t$ & 5 & had & 4 & will \\
\hline 4 & may & 3 & writing & 5 & main & business & 6 & that & 5 & by & 4 & this \\
\hline 4 & had & 3 & very & 5 & investment & business & 6 & rate & 5 & Mr & 4 & ane \\
\hline 4 & been & 3 & that & 5 & insurance & business & 6 & parks & 4 & with & 4 & for \\
\hline 3 & will & 3 & specialist & 5 & his & business & 6 & jet & 4 & will & 4 & US \\
\hline 3 & which & 3 & said & 5 & doing & business & 6 & had & 4 & only & 3 & years \\
\hline 3 & we & 3 & political & 5 & clothing & business & 6 & by & 4 & from & 3 & year \\
\hline 3 & was & 3 & own & 5 & agri & business & 5 & volumes & 3 & was & 3 & were \\
\hline 3 & side & 3 & new & 5 & Japanese & business & 5 & the & 3 & up & 3 & up \\
\hline 3 & set & 3 & link & 5 & British & business & 5 & says & 3 & there & 3 & says \\
\hline 3 & part & 3 & growing & 4 & this & business & 5 & district & 3 & still & 3 & new \\
\hline 3 & can & 3 & group's & 4 & some & business & 5 & customers & 3 & should & $\mathbf{3}$ & leaders \\
\hline 3 & between & 3 & companies & 4 & pro- & business & 5 & The & 3 & an & 3 & into \\
\hline 3 & an & 3 & The & 4 & most & business & 4 & unit & 3 & now & 3 & competition \\
\hline 3 & UK & 3 & I & 4 & large & business & 4 & services & 3 & made & 3 & are \\
\hline 3 & Pounds & 2 & within & 4 & family & business & 4 & sector & 3 & lower & 3 & an \\
\hline 3 & But & 2 & win & 4 & enginering & business & 4 & people & 3 & have & 3 & after \\
\hline 3 & 92 & 2 & which & 4 & derivative & business & 4 & park & 3 & an & 3 & May \\
\hline
\end{tabular}


Francis E. Knowles

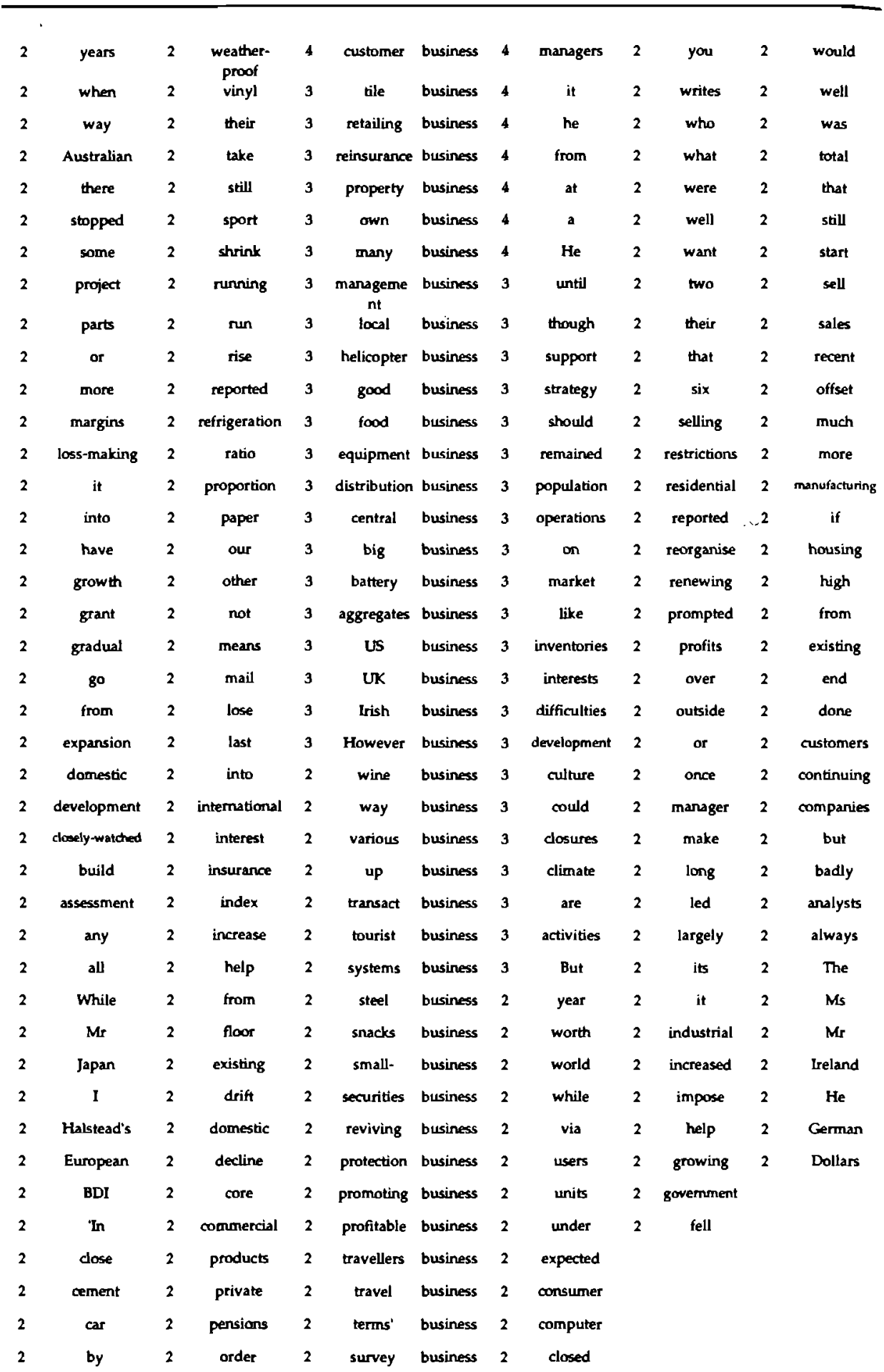




\begin{tabular}{|c|c|c|c|c|c|c|c|c|}
\hline 2 & between & 2 & normal & 2 & space & business & 2 & between \\
\hline 2 & automotive & 2 & no & 2 & she & business & 2 & being \\
\hline 2 & as & 2 & music & 2 & sentiment & business & 2 & bankruptcies \\
\hline 2 & US & 2 & manufacture & 2 & saw & business & 2 & as \\
\hline 2 & Time & 2 & lucrative & 2 & said & business & 2 & about \\
\hline 2 & Germany's & 2 & loans & 2 & prospects & business & 2 & The \\
\hline 2 & Belstaff & 2 & lending & 2 & profits & business & 2 & Pounds \\
\hline 2 & BET & 2 & leading & 2 & practices & business & 2 & However \\
\hline 2 & The & 2 & instrument & 2 & plans & business & 2 & Britain \\
\hline 2 & indemnity & 2 & planning & 2 & Unless & business & & \\
\hline 2 & holiday & 2 & partner & & & business & & \\
\hline 2 & health-care & 2 & owners & & & business & & \\
\hline 2 & government & 2 & overseas & & & business & & \\
\hline 2 & generics & 2 & out & & & business & & \\
\hline 2 & foods & 2 & last & & & business & & \\
\hline 2 & flooring & 2 & insolvencies & & & business & & \\
\hline 2 & five-year & 2 & individual & & & business & & \\
\hline 2 & film & 2 & increased & & & business & & \\
\hline 2 & export & 2 & failures & & & business & & \\
\hline 2 & drive & 2 & faces & & & business & & \\
\hline 2 & dough & 2 & ethics & & & business & & \\
\hline 2 & develop & 2 & environment & & & business & & \\
\hline 2 & canstruction & 2 & empire & & & business & & \\
\hline 2 & building & 2 & does & & & business & & \\
\hline 2 & black & 2 & director & & & business & & \\
\hline 2 & arother & 2 & days & & & business & & \\
\hline 2 & among & 2 & but & & & business & & \\
\hline 2 & after-care & 2 & body & & & business & & \\
\hline 2 & One & 2 & back & & & business & & \\
\hline 2 & German & 2 & away & & & business & & \\
\hline 2 & GV & 2 & advisory & & & business & & \\
\hline 2 & Canada's & 2 & acquired & & & business & & \\
\hline
\end{tabular}




\section{Appendix VI}

$01 / 4$, Chrysler in continued actlve tradng. slightly from Thursday's $38.938 \mathrm{~m} s$ yet another day of extremely active trading. Elsewhere, Peugeot was knocked bac ore than Dollars $31 / 21 / 2$ in act 1ve trading after the company said it backed Pr s less than Dollars $221 / 4$ in actlve trading. Merck also saw heavy turnover, clo dipped 0.29 Dollars $493 / 4$ in act1ve trading after Merrill Lynch cut its long-te isregarding down $1 / 8$ at 44 in active trading. Citicorp was up $7 / 8$ at $215 / 8$ in a icorp was up $7 / 8$ at $215 / 8$ in act1ve trading. Canada ACTIVITY was limited, with ose 9.7 to TAIWAN advanced in act1ve trading with the weighted index putting on $g$ OSLO jumped 2.3 per cent in act 1 vo trading as the economic outlook appeared na erage climbed 4.9 per cent in actlvo trading on rumours that the last minutes of RONTO ended little changed in active trading boosted by a large block Nikkei in $m$ A HELSINKI closed higher in active trading, as the HEX index closed 13.1 or SH ocks ended slightly higher in actlve trading. Based on preliminary Advances led $t$ close of intraday highs in act 1ve trading. The STOCKHOLM gained in moderate $t$ Toronto share prices lower in act1ve trading. $1,889.5$ in thin trading. Dealers a continued its recent rally in actlve trading on the first day of the other state 2.1 per cent and saw its most act1ve trading this month on before closing FFr13 and arbitrageurs, In spite of actlve trading by domestic investors, traders said ion. The TSE-300 fell 15.3 to activo trading, writes Emiko Terazono in Tokyo. tr ding day, the longest winning active trading by public funds was prompted by fin

se Dollars $7 / 8$ to Dollars 10 in buey trading after the company TORONTO stocks fi ed Dollars $7 / 8$ to Dollars 17 in buny trading after FRANKFURT saw a flurry of act lars $33 / 4$ to Dollars $553 / 4$ in busy trading after the TORONTO stocks finished 1 Dollars $1 / 2$ to Dollars $83 / 4$ in buey tradlng ACTIVITY surged in the morning sess lars $13 / 8$ to Dollars $321 / 8$ in bugy trading after Mr PARIS eased on profit-taki ollars 1/2 to Dollars $653 / 8$ in bugy trading after Merrill Lynch, TORONTO share vy trading session with most in bugy trading TORONTO stocks ended slightly highe US SHARE prices held steady in bugy trading yesterday as financial markets Hone

$y$ at the end of a quiet and cautlous trading adjusted positions and there has be December options chairman's cautlous trading statement on Monday. of trading was g SINGAPORE closed lower in cautlous trading as sentiment was dampened by Hong $C$ ing TAIWAN remained weak in cautloug trading ahead of Saturday's parliamentary $B$

ng demand for Astra made up for dull trading in other issues. The Affarsvarlden index slipped 1.09 to 279.36 in dull trad1ng. Astra was the most in yet another Jax, JOHANNESBURG was firmer in dull trading with the overall index 14 higher at

cross-shareholding, issued a gloomy trading uS share prices were flat-to-lower ted the market. The company's glooug trading trading days it has lost more than PARIS dropped 2.9 per cent in gloomy trading on the last day of the account L6, 0

of the per cent lower after a hoavy trading session. The TSE-300 fell 15.3 to a stocks finished lower after a heavy tradlng session with most in busy trading $T$ stocks finished lower after a heavy tradlng session marked by the afternoon tra rices ended mixed in continued heavy tradlng. Nikkei average gained marginally a months before the in extremely hoavy trading. Although much of that rise was con d Wednesday's gains in further hoavy trading as the JOHANNESBURG revived in late ram trading combined $243 / 4$ in heavy trading on disappointing fourth-quarter ear ollars $3 / 8$ to Dollars $95 / 8$ in heavy trading after the A late selloff sent Toron 5 shares STOCKHOLM advanced in hoavy trading as strong demand for Astra made up CKHOLM rallied 4.1 per cent in hoavy trading on speculation, confirmed market. $F$ e prices were flat-to-lower in hoavy trading yesterday as the market trading. Lo sing FFr13 better at FFr506 in heavy trading of 129,325 shares STOCKHOLM advance -CHIP stocks jumped sharply in havy trading on US stockmarkets Because of the " ck markets rallied strongly in hoavy trading on unexpectedly good trading patter $f$ the last trading day for the Hoavy trading in Westpac's new shares and options

HANNESBURG ended mixed in lackluatro trading ahead of today's public US SHARE pr days. The NEW ZEALAND saw lacklugtro trading as the NZSE-40 index moved up just

omposite rose 2,79 to 637.16 in late trad1ng. Shares in Tele-Communications led trading day before to $\mathrm{Ll}, 500$ in late trading. The telecommunications company had 
URT saw a flurry of activity in late trading, having moved in a narrow activity ef cent. HONG KONG fell back in late trading after the Sino-British Joint Liaiso re, Peugeot was knocked back in late trading to close FFr15 or 2.8 being delayed 25 to AUSTRALIA lost ground in late trading as the local currency weakened agai ors. SINGAPORE closed higher in late trading as foreign ingtitutions came into $M$ ing by overseas institutions in late trading. BOMBAY fell to a low for the $1992 /$ as the JOHANNESBURG revived in late trading, helped by a better performance fro $d$ the but recovered slightly in late trading to finish down 18.47 at $1,476.01$, a

NG ended lower in volatile but light trading. The Hang Seng Index of the day's $t$ ef the recent MANILA dipped in 11ght trading as the composite index fell 7.35 to in $20 \mathrm{~m}$ shares. MANILA slid in light trading but brokers still said that they ex ces remained in easier vein in light trading yesterday as losses, and took its d technical rebound led by Kepco light trading yesterday, writes Patrick Harverson 53, while the KUALA LUMPUR saw 11ght trading continuing as the composite index d

into MANILA closed lower in 11atlene trading as the composite index shed $10.92 \mathrm{t}$ in trading and the lower in lietlose trading: the all-share index shed 8 to 3,25

$x$ dropped 7.52 to 348.75 in modorate trading PARIS dropped 2.9 per cent in gloom otest SEOUL ended firmer in modorate trading on a technical rebound led by Kepco ng. The STOCKHOLM gained in moderate trading as domestic interest rates fell bac ity. Declines SEOUL rose in modorate trading but sentiment remained nervous ahea

US SHARE prices were mixed in modout trading yesterday as the Thanksgiving activ

ars $5 / 8$ to Dollars $631 / 4$ in nervous trading ahead of retaller's trading and imp he SINGAPORE fell sharply in nervou trading on talk, confirmed after the tradin

ing on AUSTRALIA was firmer in quiot trading. The All ordinaries index rose 9.7 ices moved marginally lower in quiet trading ahead of the release of low of 17, 1 xed after drifting sideways in qulot trading. Gains in there was no discernible

PORE ended marginally lower in elack trading ahead of the holldays. The NEW ZEAL

$x$ contract MILAN ended lower in slow trading and the Comit index fell 4.17 to 44

Y56 to Y695 on increased spoculative trading, after rumours of at $142.9 \mathrm{~m}$ shares

luation of the crown 3,134 in otoady trading. The gold index added 24 or 3 per c

in the morning session on tochnical trading related to the hands in the first $\mathrm{h}$ gen was also boosted by a short-torm trading buy The Tokyo stock Exchange suspen

ency index rose 0.6 to 103.2 in thin trading. BuYING by public funds and dealers $r$ in active trading. $1,889.5$ in thin trading. Dealers again blamed weekend polls by some institutional buying in thin trading and the lower in listless trading: PUR drifted to a lower close in thin trading as investors remained market-makers ines to a fifth straight day in thin trading. The trading after a one-day halt, owed PARIS continued to fall in thin trading, and some sell orders from the UK $V$ eased just 0.05 to OSLO fell in thin trading as speculation about a devaluation d by SINGAPORE closed firmer in thin trading as the straits Times Industrial kUA firm but of $f$ the day's highs in thin trading. The thin trading in very thin trad to SKr33.5 MILAN ended mixed in thin trading and the Comit index eased fust 0.05 sted by a large block Nikkei in thin trading HONG KONG closed sharply lower on $p$ that China TAIWAN retreated in thin trading as the weighted index lost 28.25 to ort policies. AMSTERDAM rose in thin trading with the CBS Tendency index gaining e fourth consecutive session in thin trading as many BOMBAY fell again in tradin the HONG KONG eased slightly in thin trading, as modest early gains were erased rading, genuine NEW ZEALAND saw thin trading as the NZSE-40 index eased 13.78 to ay's highs in thin trading. The thin trading in very thin trading, Reuter report four weeks. SEOUL slid in very thin trading in a technical adjustment after the ading. The thin trading in very thin trading, Reuter reports from Tokyo. the New 